\title{
Revitalization of Local Wisdom in Environmental Education
}

\author{
Iman Hilman \\ Department of Geography Education \\ Siliwangi University \\ Tasikmalaya, Indonesia \\ Corresponding email: imanhilman@unsil.ac.id \\ Nedi Sunaedi \\ Department of Geography Education \\ Siliwangi University \\ Tasikmalaya, Indonesia
}

\begin{abstract}
Local wisdom that exist nowadays is facing challenge that threaten its preservation, so that it begins to erode by the development of technology, which has adoption process of innovation and the diffusion of technology adoption. Understanding the local wisdom would be clear that local wisdom becomes important in managing natural resources and conserving environment. The purpose of this research is to revitalize and preserve the local wisdom of the indigenous community at Kampung Kuta, Ciamis Regency, and West Java. The benefits of this research will be used for revitalization and preservation of local wisdom and revitalize the values and cultural norms contained in regulating the life of community. The research method and planning that would be applied in this revitalization and preservation of cultural is Participatory Planning and Research (PPR) which emphasize on excavate information through thorough inquiry toward local community. Share with the community, to talk about how to empower local community and furthermore to carry out the useful planning for local community. Design of revitalization and preservation of local wisdom; the establishment of local wisdom group with training and learning program; the management of indigenous group continuously; spread widely local wisdom to its supporter with instilling cultural values and local wisdom as a contain of local wisdom; plan regeneration agent and the supporter of local wisdom as a part of inheritance of culture. Revitalization and preservation of local wisdom in educational environment at Kampung Kuta custom produce: cultural tradition management; help and support for cultural development; promoting and introducing cultural tradition to the outside community.
\end{abstract}

Keywords-Revitalization, conservation, preservation, Local Wisdom, Environmental Education

\section{INTRODUCTION}

Indonesia is a country that has variety culture from different tribes as an assets of intellectual and cultural. The variety of culture can be a potential or challenge to be withstood as a part of cultural inheritance that must be maintained. Traditional values of the culture from different place, time, and community have so many local wisdoms which is relevant with the condition nowadays.

Culture is dynamic, continuous to grow, moreover if the potential of the agents of culture is developed and the dynamics is activated through the education (Sardjiyo, 2005). So many regions in Indonesia has local wisdom which was caused by the interaction process between human and their environment to fulfill the need of living. The experience in fulfilling the need of living, has produced various systems of knowledge which related with environment and social.

Local wisdom is one of the product of cultural community that formed because the necessary of value, norm and rule as a model to do something action. In relation with this concept, Forde (1934) describe the essence of relation between human and their natural environment is united by human cultural pattern.

Kuta indigenous community as an indigenous community in Ciamis Regency, West Java Province still applies the tradition which the caretaker and the leader of community are doing surveillance. Community obey the rules as a form of reliance to their custom as taboo that should be run and faith to the existence. The belief to the taboo and magic power still alive in the entire community.

The local wisdom of Kampung Kuta has a function as social institution that can control the manner of human in interaction process with the nature and the other human being.

Civilizen or cultured human is the human who have had control and act in accordance with cultural values especially ethical values and moral that exist in that culture (Bintarto \& Hadisumarmo, 1982). This is also related with the definition of "Educated Man" which has meaning that educated man is the civilizen or cultured man, because this definition comes that education is cultural aspect. So that, someone who developed appropriately with their culture is someone who also developed his/her education since they have the same purpose in 
personality development in the culture that the education occurs.

Education is a process of civilizing and as a tool for cultural changing. This process occurs in any form of inheriting cultural tradition from one generation to the next generation and through the process of cultural tradition adoption for them who has not known the cultural before.

Cultural values and local wisdom need to be developed as an integral part of education from any kind and stage. The development of local wisdom education will not be carried out well without an optimal participation from community. Bring everyone and every units of community to take a part and being organizer of education program are worth contribution and should be given attention and appreciation. The principal duty of education is inheriting cultural value in accordance with the potential and environment condition.

In this case, Goldberg (2010) stated that education with cultural base is a strategy of creating learning environment and planning the experience of learning which integrate cultural as a part of learning process. Through cultural base education, student and community not only imitate and/or accept delivered information but they also create sense, comprehension, and meaning from information they have accepted.

Tilaar (2000) view stated that basically education, community and culture are single tripartite. It has meaning that culture as a basic, while community as a provider of facility, and education as an activity which conserve and develop cultural values which bind life together in community. In this case, community is the owner of that culture.

Local wisdom that exist nowadays is facing challenge that threaten its preservation, so that it begins to erode by the development of technology, which has innovation adoption process and the diffusion of technology adoption. The other factor is the quantity of inhabitant, poverty, and social gap.

To anticipate the problems, local wisdom which is prevailed in community hereditarily and has close relation with environment sustainable should be preserved by understanding the local wisdom becomes an important thing in natural resource management and conserving environment.

Research about local wisdom role of Kampung Kuta community in environmental education with using nature as a facility is important to do in order to get holistic comprehension. Local wisdom as an object of the research is holistic, because relate with knowledge and comprehension about entire life with all relation in the universe. Keraf (2010) asserts that "nature is wide life net, wider than only amount of divided part, Nature is relation series which connected one another, and so, the comprehension and knowledge about the nature should be comprehensive knowledge".

\section{METHOD}

\section{A. Methods of research}

The research method and planning that would be applied in this revitalization and preservation of cultural is Participatory Planning and Research (PPR) which emphasize on excavate information through thorough inquiry toward local community. Share with the community, to talk about how to empower local community and furthermore to carry out the useful planning for local community (Semiawan, 1992).

This method is the development of Rapid Rural Appraisal (RRA) method and Participatory Rural Appraisal (PRA) method. Rapid Rural Appraisal (RRA) method emphasizes on comprehension and learning to the rural community from the outside who gives attention and care to community inside. Participatory Rural Appraisal (PRA) method emphasizes to the collectively comprehension by the community to make the member of community share and care one another to empower the community.

\section{B. Research Sites}

The object of this research is local wisdom of Kampung Kuta community to develop the reconstruction of cultural values and local community. The object of this research is about local wisdom that has a role in living environmental education. In order this research produces comprehensive study, we should determine the research location which has and applies local wisdom to love, take care, and preserve its environment through planning the model of revitalization and preservation of local wisdom in environmental education with Participatory Planning and Research method.

\section{FINDING AND DISCUSSION}

The result of research shows that Revitalization of local wisdom in environmental education can be elaborated from adaptive behavior using unique steps in facing environmental problem, as follows:

\section{A. Instilling Principles to Love The Environment}

Instilling principles to love the environment is one of the purpose of local wisdom to build the character of young generation in order has personality and character that love peacefulness and prosperity. It has same argument with Sibarani (2014), that " local wisdom function as an instrument for personality and good character building, the sign of identity or community identity as adhesive element in social cohesion, as world view or base of thinking with community and as a basic interaction in community member both internally and externally."

Instilling love to the environment as a form of cultural adaptation process (local wisdom) in environmental education in Kampung Kuta community can be seen from cultural adaptation practice they do by implementing and obeying all of the form of local wisdom such as doing the recommendation and custom tradition, and avoid impolite manner in a form of taboo. 
The practice of cultural adaptation can be seen from the catchword and community's slogan which always be socialized from one generation to the next generation, the sentence is "leuweung ruksak, cai beak, manusa balangsak" (forest damaged, no water, human live in suffering). Leuweung Gede forest preservation for indigenous community is like an artery, sustain community life, and symbol the development of culture.

The principle has a deep meaning about how important the forest is for the living of Kampung Kuta community. Availability of the ground water is depended on forest preservation. The slogan is socialized by placing it in the middle of village and is always socialized by the family and the custom institution through the customary rule as a taboo to every individual of Kampung Kuta community.

Moral values which is contained in the slogan could be used as a basic to manage environmental continuously, because it contains principle: the eternal values, friendly environment, the awareness of ecological, and care about social life. Instilling attitude that love the environment is an important thing to create behavior pattern to be friendly nature.

The process of environmental education has a relation with the environment around us. Environmental education not only in the class. Learning with environmental approach will make it not boring and creates human being who loves the environment.

\section{B. Caring and Maintaining The Environment}

Caring and maintaining the environment are an important thing to do by the community to create conducive environment. Like what Soemarwoto (1983) said "managing the environment can be meant as an effort to maintain or and to improve the quality of environment in order that the primary need of human being could be fulfilled as good as possible.

Keep the cleanliness of the environment is the implementation of cultural adaptation by Kampung Kuta community on caring and maintaining the environment. Every Sunday, indigenous community cleans jalan setapak (little path) in the middle of the sacred forest from the gate to Pamekaran crater. It reflects togetherness value and mutual assistance value still exist. Kuta community still have a sense of responsibility, especially on conserving the forest it can be seen from their effort to take their time and their energy for that activity.

The obedience of the community to the customary rules, they clean the path only using a broom made of such splintered ribs, wood, and bamboo. It makes the path in the forest always look clean and natural. Community is not allowed to use the tool that made from iron such as mattock, sickle, machete, etc., because they afraid it would destroy the condition in the forest. They realize wickedness happen when there is an opportunity and aim, so no matter how slight the opportunity, it has to be avoided and obey the rule.

The culture of mutual cooperation to clean the forest makes the cleanliness of the forest is maintained well. It makes the people who want to visit into the forest easy to walk on the path. Besides that, to keep the totality and forest conservation, every month, caretaker and some of indigenous community are doing patrol surround the sacred forest. It has a functions to take care from people who want to destroy the forest or steal the wood (cut the trees).

Local wisdom in this community is important to take care and conserve the environment. Not only aware, but also morality and spirituality belief if human being live and unite with nature. It will emerge harmonization and give benefit to each other.

This condition has the same argument like what Bintarto (1982) said that human being as an individual or groups, live in the nature and environment. From the close relation and reciprocal, human being takes some adaptation, even the human being do conservation.

\section{Overseeing and Conserving The Environment}

One of the role of local wisdom is overseeing and conserving the environment. One of the implementation of this activity to give the visitor guidance when they want to enter the sacred forest in order them safe during the activity until the end of activity in sacred forest.

All of your hope can be delivered to the master of the nature through the caretaker in sacred forest except you are asking for wealth and ideal that incompatible with the norm. Before praying (ngarekeskeun) guest's aim, caretaker always said "Ka Ambu, Ka Rama, Ka Bima Raksa Kali Jaga nu linggih di Kuta jero". That name is always mentioned in ritual events, to ask permission. Ka Ambu expression has a meaning "to mother" and Ka Rama expression has a meaning "to father", $K a$ Raksa expression as a request to take care our self, $\mathrm{Ka}$ Bima Kali Jaga expression is a request symbol to something who is strongest.

It shows a tight relation between Kuta communities with ancestor as a guard of environment. Kampung Kuta community belief if invisible creatures which is regarded as delegation of God The Most Infinity Power which is believed exist in Kampung Kuta region and always keep the safety, wealth, and harmonization in Kampung Kuta community.

Kuncen (caretaker) is one of the leader, has a duty to manage the forest and ritual event in holy place, Leuweung Gede which is secreted. Kuncen has a big power to manage the forest in Kampung Kuta. No one can oppose kuncen's power in managing sacred forest. Sacred forest or Leuweung Gede which is believed by the community as a holy place, place for worship where they can communicate with ancestor's soul that master sacred forest.

\section{Utilizing Natural Resourches}

Utilizing natural resources for economic activity at some livelihood which concentrate in agriculture field. Beside the support of the natural factor, it's also because the rule in Kampung Kuta that is obeyed by the community. 
Many of Kampung Kuta community's activity is adopted from local wisdom, among of them is in paddy field, after harvest the rice is finished and dried, then the rice is saved in Leuit (granary or rice barm). Leuit is a place to save the rice which is traditionally still used by Kuta community to keep the food availability of indigenous community. Usually, Leuit is placed near Saung Lisung (rice crusher). But leuit and saung lisung barely to be found because nowadays Kuta community uses rice mill service.

Like in rice field agriculture, the process of making palm sugar also have known clear division of tasks. The man take palm water (nira) which is called as nyadap (tapping). The woman is processing the result of tapping, begin from lahang until become sugar. There are division of task and responsibility in this activity.

Utilizing forest by the community usually is based on inheritance of ancestor hereditary, and refer to customary law which prohibit exploitation.

\section{E. Applying Taboo in Conserving the Forest}

In daily life, Kuta community always runs Islamic shari'a as their religion but in the other side they also obey to the custom as an inheritance of ancestor (karuhun). They don't care the rules come from their religion or custom. Religion and custom have become guidance which complement each other. Union of custom and Islamic religion make the taboo run together well.

- In Kuta community there are various taboos that have relation in effort to conserve the environment:

- Don't disturb animals and take anything in the forest to your home. Indigenous community believe that if someone disturb the animals or the plants, or take something from the forest even only a twig, it would bring disaster.

- Taboo to spit, urinate, and defecate in sacred place. This taboo appears because there is a presumption that sacred forest is a holy place that have relation with the spread of Islamic religion in Cirebon, they assume and treat the forest region as a holy place or "mosque"

- Taboo to bring tools that made of iron such as sickle, machete, if we don't obey the rule, ancestor would be angry. It would be showed by the disaster hits indigenous community.

- Taboo to throw garbage containing fire. This prohibition comes from the habit of $\mathrm{Ki}$ Bumi who always extinguish cigarettes he smoked when he enter the sacred forest.

- Taboo to entomb human corpse, prevent the fire occurrence and don't pollute the forest by waste, in Kampung Kuta. Community does it to respect ancestor, $\mathrm{Ki}$ Bumi who was entombed outside the area of
Kampung Kuta, exactly in Cibodas village and Margamulya.

- Taboo to make a house from wall materials, and don't use roof-tile as a roof but it must use kirey and fibers. Roof-tile is made of soil sould be beneath as a foothold of human. But you have to use kirey or flam fiber for your roof. Using roof-tile as a roof means you support (nyuhun) to the ground/soil.

- Taboo to make well, especially drill well. The community believe that if we big the land exceed adult's knee, it would damage the inheritance of the ancestor that has been given to us. In this taboo there is environmental wisdom in relation with the soil in the village which has unstable character. Besides that, drill well can cause ground water availability disturbed, especially when all community does this activity.

\section{F. Applying Taboo in Daily Activity}

Beside taboo for preservation of nature, Kuta community also has taboo relate with our activities in daily life, as follows: Taboo for person who want to enter the forest; Taboo to say bad words and impolite because it will disturb the peacefulness of ancestor who live in Kampung Kuta, especially Leuweung Gede; Taboo to performing puppet; Taboo to wear sarong when nyadap (tapping); Taboo to go to the toilet (tampian) in the middle of the day or dzuhur time; Taboo for girl to stay or take a long time in the toilet; Bring torch when we go in the evening; Taboo to eat butuh (coconut which sprout) for the woman who is pregnant; Taboo if man enter the goah (place to save every of kitchen needs); Taboo to marry ex. wife and ex. husband of brother or sister; Taboo to wear "sinjang jangkung" for the woman who is pregnant; Taboo if we don't sleep in the same room for a week after married; Taboo to go to toilet in sunset (magrib) time; Taboo to eat while you stand up.

\section{G. Implement Traditional Ceremonies}

Kuta community has many activies and related with mystical value based on local knowledge they have. All of life activity has a close relation with faerie and ancestor that should be respected. The manifestation of homage is implemented in form of traditional ceremonies that they always do. There are general traditional ceremonies and traditional ceremonies for person who want something. These are kind of general traditional ceremonies : Nyuguh; Sedekah (hajat) Bumi; Babarit

\section{H. Build House}

Kuta community has system of knowledge and local technology from traditional values which develop in community. System of knowledge and technology that had been developing in a long time ago runs concurrently with the development of Kuta community. It means the values had been doing some adaptation with the values that comes from the outside, because there are not culture that always run static, include the culture of Kampung Kuta. 
Someone has to get "lucky day" that has been counted by Puun (someone who regarded as an old person and has cleverness in their own field). The goal of this Day-Counting is in order the house which have been established give them blessing, healthy, safety, and easy to get fortune.

Regardless from right or wrong, the essence of this daycounting to decide something accurately. In modern management, planning is the first step in a series of activity. Good planning will get the result as good as we want.

Kuta community always does the ritual before and after doing something (hajat). for example when people want to build a house (ngadegkeun) and stay in it. Ritual has been begun when someone do the first milestone. Usually, community comes to Puun to know the lucky day to start to build a house in order that we know the place we have built is a good place or not. Community calls this process as diteya.

After getting the illustration about the lucky day and place to build the house, community conduct syukuran or selamatan (sign our grateful to God) begun with intermeeting the head of chicken in place where house would be built. The ritual is led by puun with hope that the process of building a house will run well and the house gets blessing from ancestor and natural ruler. Kuta community has a unique tradition, they save ritual offering (sesaji) in fence post (wuwung genting) and stick white-red cloth as a sign of Indonesian flag to show they love Indonesia. They do it at the end of the process of building a house.

The ceremony as a sign of gratitude after finishing building the house is done by inviting the neighbor to pray together and led by puun. After ritual, every of guest eats ceremonial dish of yellow rice served in a cone shape (Nasi Tumpeng) together. The essence on this moral value is the importance of planning before doing something, respect and togetherness.

In building a house and residence, Kuta community always holds on to the aphorism or message from their ancestor in sundanese "ulah rek dikubur hirup-hirup, ulah ngabangun istana jadi astana" it has a meaning don't be buried alive, don't build palace (house) becomes tomb".

If we relate this aphorism with the earthquake, it guides especially to Kuta community and generally to us to build a house that resistant to an earthquake. It can be proved when earthquake occurred, there were no house damaged because the specification of indigenous community's house resistant to an earthquake, and if only the construction is damaged, the effect would not be so serious when the construction befall to the occupant, because the roof is made of sago palm (rumbia) or palm fibers.

\section{CONCLUSIONS AND SUGGESTIONS}

Design of revitalization and preservation of local wisdom; the establishment of local wisdom group with training and learning program; the management of indigenous group continuously; spread widely local wisdom to its supporter with instilling cultural values and local wisdom as a matter of local wisdom; plan regeneration agent and the supporter of local wisdom as a part of inheritance of culture.

Revitalization and preservation of local wisdom in education at Kampong Kuta custom poduce: cultural tradition management; help and support for cultural development; promoting and introducing cultural tradition to the outside community.

\section{REFERENCES}

[1] Bintarto, R., \& S. Hadisumarmo, 1982, "Metode Analisa Geografi", Jakarta, LP3S.

[2] Forde, C.Daryll, 1934, "Habitat, Economy, and Society, London

[3] Goldberg, D.F, (2010), "The Missing Basics and Other Philosophical Reflections for the Transformation of Engineering Education", In: D.Grasso, \& M.Brown Burkins (Eds), Holistic Engineering EducationBeyond Technology, (pp.145-158), New York, Dordrecht, Heidelberg, London, New York: Springer.

[4] Keraf, A. Sonny, 2010, “Etika Lingkungan Hidup”, Jakarta: Penerbit Buku Kompas.

[5] Sardjiyo, Paulina Pannen, 2005, "Pembelajaran Berbasis Budaya: Model Inovasi Pembelajaran dan Implementasi Kurikulum Berbasis Kompetensi", Jurnal Pendidikan, Vol.6 No.2: 83-98.

[6] Semiawan, Conny, 1992, "Pendekatan Keterampilan proses", Jakarta: PT Gramedia.

[7] Sibarani, R., 2014, "Kearifan Lokal: Hakikat, Peran, dan Metode Tradisi Lisan", Jakarta: Asosiasi Tradisi Lisan (ATL).

[8] Soemarwoto, O., 1983, "Ekologi, Lingkungan Hidup dan Pembangunan", Jakarta: Djambatan.

[9] Tilaar, H.A.R., 2000, "Pendidikan Kebudayaan dan Masyarakat Madani Indonesia: Strategi Reformasi Pendidikan Nasional”, Bandung: Remaja Rosda Karya. 